\title{
Construction of Interdisciplinary Training Platform for Shipping Talents
}

\author{
Ying Zhang ${ }^{1,2, *}$ Xiaoyi Chen ${ }^{1}$ Qingying Zhang ${ }^{1}$ Dexin $\mathrm{Tao}^{3}$
}

\author{
1 School of logistics, Wuhan University of Technology, Wuhan, China \\ 2 Engineering Research Center of Port Logistics Technology and Equipment, Ministry of Education, Wuhan, China \\ 3 Yangtze River Shipping Industry Research Center, Wuhan University of Technology, Wuhan, China \\ *zhangying2003@whut.edu.cn
}

\begin{abstract}
In order to train high-quality shipping talents, solve the problem of lack of shipping talents and promote the development of shipping industry, this paper suggest the construction of interdisciplinary training platform for shipping compound talents from the perspectives of enterprises, colleges and industries. The platform integrates various related high-quality educational resources, and has three different talent training bases according to different talent training modes, namely, college-enterprise cooperation training base, enterprise-set training base and open training base. In addition, the platform also has talent training expert database and online course resource library. In this paper, the general idea of building this training platform for shipping compound talents is introduced in detail, and the construction of three bases and two resource databases that constitute the platform is explained in detail. The construction of this platform is of great significance to promote the development of the high-level shipping talents training.
\end{abstract}

Keywords: Shipping compound talents, Interdisciplinary, Training platform, Expert database, Online. course resource.

\section{INTRODUCTION}

Transportation is an important tool of rejuvenating the country and the foundation of strengthening country. In today's new era of high integration development of Internet economy, information technology and shipping economic, and rapid development of modern shipping service industry, the contradiction between supply and demand of shipping talents, especially high-level shipping compound talents, has become a bottleneck restricting the rapid development and sustainable development of shipping industry.

There is an increasing demand for shipping talents in the shipping industry, and many scholars have taken relevant researches on the development of shipping talents. Through investigation and SWOT analysis, Jiang Jun analysed the development status of shipping talents in Chongqing, and put forward corresponding countermeasures and suggestions [1]. Yang Dagang analysed and compared the training curriculum system of shipping finance talents in 10 universities at home and abroad, and suggested the teaching mode of combining industry, education and research [2]. Qu Qunzhen obtained the talent training mode of "government, industry, university and research" by analysing the main training modes of shipping talents in foreign countries and the current training situation of shipping talents in China [3]. Lai Yongsheng studied and analysed the training mode of shipping talents, and suggested the training mode of "goal, system and regulation" [4]. Yin Ming analysed the typical problems in the training of shipping professionals, and based on the thought of supply-side structural reform, suggested the ideas and methods to solve the supply-side problems in the training of shipping professionals [5]. Wei Zhijie analysed Wuhan's importance and shipping advantages in the Yangtze River shipping economic belt, and put forward that Wuhan is the most ideal and promising high-end inland shipping talent training base [6]. Liu Lei analysed the shortage of teaching staff construction in vocational maritime colleges and put forward corresponding countermeasures and suggestions [7]. By analysing the influence of "the belt and road initiative" on shipping education and training of high-quality shipping talents, Gao Wenjing put forward some suggestions on training high-quality shipping talents in line with international conventions [8]. Wan Jianxia established a scientific evaluation system for the competitiveness of shipping 
talents by using the grey cluster evaluation model [9]. Pantouvakis analysed the role of talents in shipping industry [10]. Cheng Xiangxin put forward the training scheme and development suggestions of advanced shipping talents according to the economic development and training situation of shipping talents in Shandong [11].

In this paper, from the perspectives of enterprises, colleges and industries, it is proposed to build a training platform for shipping compound talents, so as to promote the development of the high-level shipping talents training.

\section{THE DEFINITION OF SHIPPING COMPOUND TALENTS}

The "compound" talents refer to professional and technical talents or senior management talents who are interdisciplinary, multi-level, and with compound professional knowledge background or work experience. The "shipping compound talents" mentioned in this paper refers to professional and technical talents with compound knowledge structure or management talents and innovative talents with cross-border working ability in the fields of port, shipping, shipbuilding and related service industries. The growth process of shipping compound talents is usually shown in Figure 1.

So, the current need for shipping talents should be shipping compound professionals and comprehensive management talents, involving shipping finance, logistics management, shipping economy, maritime law, shipping information, shipping consulting, shipping transactions and other related fields, those should have rich working experience and innovative ability.

\section{GENERAL THOUGHTS ON THE CONSTRUCTION OF TRAINING PLATFORM}

The construction idea of the training platform for shipping compound talents is to make full use of China's rich shipping science and education resources, and to jointly build the training platform for shipping compound talents by shipping enterprises, colleges and industries. We will build college-enterprise cooperation talent training base, an enterprise-set training base and an open talent training base. In addition, many studies show that the online course platform is not only beneficial to the dissemination of knowledge, but also can effectively promote students' learning [12-16]. Therefore, making full use of the advantages of online education, we build an expert database and an online course resource database for the training system of shipping compound talents, which will provide important support for the shipping compound talents training system. The overall architecture can be described as: one platform, three bases and two resource databases.

The training platform for shipping compound talents is the core of the whole system. It implements the functions of resource allocation, development, operation, management, service, training quality tracking, talent evaluation and so on. It integrates high-quality educational resources related to governments, enterprises, colleges and institutes, and is a public service platform for the training system of shipping compound talents, which is promoted by the governments, led by the industries and dominated by enterprises and colleges.

The construction of three bases and two resource databases is an important way to promote the training of shipping compound talents. It is of great significance to enrich the training mode, implement the training scheme, build a training platform, collect high-level teaching staff and recourse, break through the bottleneck of talent training, and drive the development of shipping compound talents.

\section{CONSTRUCTION OF TRAINING BASES}

According to different modes of personnel training, training bases for shipping compound talents can be divided into three types. The first is the college-enterprise cooperation talent training base, the second is the enterprise-set training base, and the third is the open training base for industries.

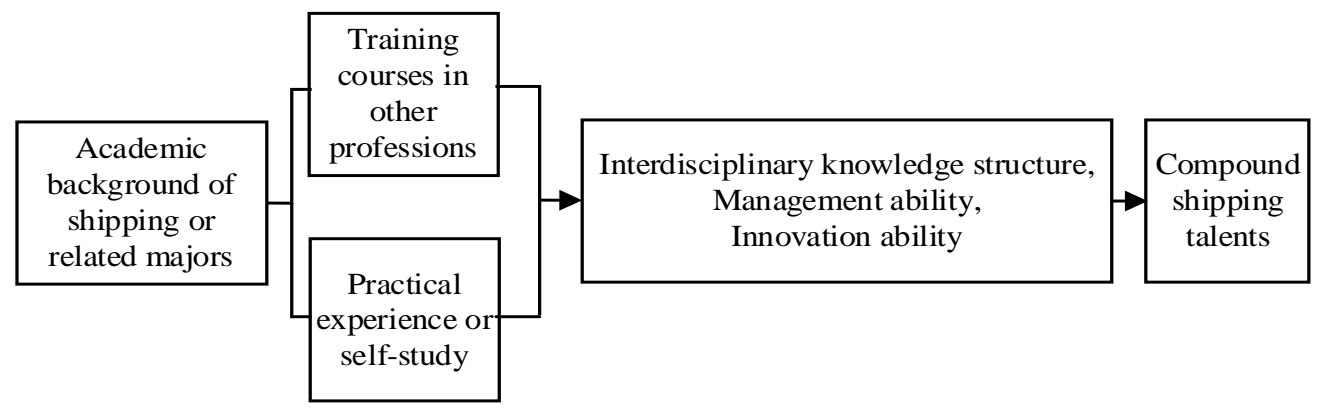

Figure 1 Growth process of shipping compound talents. 


\subsection{College-enterprise Cooperation Training Base}

College-enterprise cooperation training of shipping compound talents refers to fully relying on the superior resources of both colleges and shipping enterprises, connecting the advantages of theoretical research and teaching resources of colleges with the advantages of production practice experience of enterprises, and jointly training compound talents needed by the industry. Generally, bilateral cooperation training mode is adopted, relevant cooperation agreements are signed, and the base is set up in colleges or enterprises. The main forms include cooperation training base for outstanding engineers, cooperation training base for talents, practical training base, quality education base, postgraduate workstation, teaching center for engineering master, etc., and employ professionals from partners as part-time professors, part-time teachers or part-time tutors.

Taking Wuhan as an example, Wuhan is rich in higher education resources, and there are plenty of colleges and universities specialized in shipping, shipbuilding, traffic management, logistics, IT, finance, trade, law, insurance, etc.. At the same time, there are many shipping enterprises and institutions, which provide innate advantages and convenience for the college-enterprise cooperation training of shipping compound talents. Wuhan University of Technology actively adopted a number of methods, including successively established joint talent training bases with Yangtze River Maritime Safety Administration, Shanghai Changhang Shipping Co., Ltd. and other units, and hired a number of engineers and managers with rich practical experience as part-time teachers and joint tutors for undergraduates, undertaking the task of teaching professional courses and practical guidance.

Through the college-enterprise joint training base, enterprises participate in the determination of professional training objectives and the formulation of training programs. In terms of curriculum system construction, they suggest on the knowledge structure that compound talents should possess according to the actual work of enterprises, participate in the formulation of teaching content and syllabus of related courses, and specifically undertake the task of theoretical teaching and practical guidance of professional courses, which provided important guidance for colleges and universities to train shipping compound talents. On the contrary, colleges and universities have participated in the design of training objectives and curriculum contents in the aspects of enterprise employees' induction education, professional upgrading and academic upgrading, providing high-level teachers and necessary organization and implementation support for curriculum teaching and thesis guidance. The development of college-enterprise cooperation strengthens the contact and interaction between colleges and enterprises, and effectively promotes the pertinence, effectiveness and sustainability of the training of shipping compound talents.

\subsection{Enterprise-set Training Base}

Large shipping enterprises and institutions usually set up staff training bases according to their own needs, which mainly carry out non-academic education such as new staff training and professional promotion. The main form of bases is staff colleges, training bases, training centers and extended training bases, etc. For example, the Yangtze River Maritime Safety Administration has a staff training center and a maritime skills training center in Wuhan Maritime Vocational College. The staff training center mainly undertakes various training tasks assigned by the Maritime Safety Administration of the Ministry of Communications, and the Yangtze River Maritime Safety Administration, such as the rotation training and training tasks of party members, departmentlevel cadres, young and middle-aged cadres and grassroots cadres in the Yangtze River shipping system, tracks relevant education and training information at home and abroad, and provides suggestions for that training tasks. The maritime skills training center is mainly responsible for maritime system knowledge update training, initial training and other talents training arranged by superiors; It undertakes inland water safety supervision, search and rescue training as well as its related research and social rescue assistance training such as water search and rescue volunteers. Besides, it is responsible for formulating the training model, its rules and course modules in the Yangtze River Maritime System, organizing online training and modern distance education. Moreover, it establishes and manages a database for maritime training teachers, which contributes to the job qualification training required by international compliance regulations.

The enterprises' own training base is usually equipped with necessary software and hardware facilities, and adopts various training modes such as executive training classes, targeted knowledge development specialized classes, enterprise internal training classes, short training classes, open courses of knowledge development, etc. Detailed regulations are formulated in terms of personnel level, training objectives, learning cycle, course content, teacher sources, organization and implementation units, etc.. The training is provided for internal employees or for four major enterprise groups in spot, shipping, shipping and service and relevant government functional departments.

\subsection{Open Training Base}

The broadness, diversity and complexity of the connotation of shipping compound talents determine the necessity and urgency of establishing an open talent 
training base. Open training of shipping compound talents breaks the limits of trainees and the training environment, openly providing accessible courses and lectures with available resources for those who need them. Open talent training has the following basic characteristics: adopting a variety of teaching and learning methods; break through all kinds of restrictions and obstacles to learning; There are rare restrictions on learners' age, occupation, region, learning qualifications, etc., and almost everyone can participate in training; Learners have certain autonomy in course selection and media use; In training, various media teaching materials and modern information technology are adopted, and face-to-face teaching is combined with distance teaching.

The open training base for shipping compound talents must be established in the form of an entity with universities, institutions, enterprises or organizations as affiliated units, with necessary facilities, equipment and management personnel. Shanghai International Shipping Research Center is a typical open training base for shipping compound talents. The center is based on the construction of Shanghai International Shipping Center, and its affiliated unit is Shanghai Maritime University. The center publishes free lecture reports every month, and regularly conducts lectures in various forms such as academic reports, market analysis and celebrity forums.

Open training base should contact shipping organizations, enterprises and colleges extensively, gather first-class experts at home and abroad, build a platform for shipping research and personnel training, track the new ideas, new technologies, new trends and new systems of shipping development, grasp the changes of shipping market, and meet the broad, diverse and complex connotation of shipping compound talents. The base should be managed in an open way, with the participation of the government, enterprises, universities, research institutions, industry associations and industry organizations, and give play to the functions of decisionmaking consultation, information release and talent service. In the training of shipping compound talents, build a high-level shipping exchange platform, contact and attract first-class experts, scholars and entrepreneurs in the shipping industry, hold training for high-end shipping talents, and organize and participate in international and domestic influential high-end forums related to shipping and logistics.

\subsection{Operation Mechanism of Talent Training Bases}

The training base is of great significance to the training quality of shipping compound talents, and a good management system and operation mechanism are the important guarantee for the construction of the base. In the aspect of base management system construction, it is necessary to build an efficient and sound management organization system, perfect a systematic and reasonable management regulation and build an intensive and feasible cooperation platform. The government should allocate special funds to actively support the construction and development of the shipping compound talents training base, and enterprises should also support and encourage employees to participate in the training.

Taking the college-enterprise cooperation training base as an example, the base needs universities and enterprises to participate in the construction and management, carry out all-round cooperation in all aspects of talent training. It established three levels of management institutions, including the collegeenterprise cooperation steering committee, the base working group and the base office, and a enterprise operation and management mode conducted by colleges and participated by enterprises, which achieve a win-win realization through co-construction and co-management, equality and mutual assistance, hierarchical management, common development and. According to the actual situation, enterprises and universities should jointly formulate corresponding systems for base construction and organization management, funds and equipment management, teaching quality management, teaching evaluation, etc., and taking into account the normal operation of enterprises and the effective development of college practice teaching. Universities and enterprises have their own social functions. To cultivate compound talents cooperatively, it is necessary to establish a college-enterprise cooperation platform to provide convenience for the cooperation between production, education and research. colleges can effectively carry out teaching activities through the platform, and enterprises can find urgently needed professionals through the platform.

In addition, the construction of the base needs a sound, reasonable and effective operation guarantee mechanism to ensure the needs of funds, personnel and facilities for the operation of the base. According to the principle of equality and mutual assistance, the relevant constructors of the base are jointly provide funds, equipment and facilities of the base, and the base working group is responsible for the implementation and supervision of the use of funds and equipment to ensure that the base construction and training plan is implemented on schedule.

Base construction needs to establish a mutually beneficial resource sharing mechanism. Resource sharing is an important foundation for college-enterprise cooperation or open talent training. Participants in base construction should share resources in talent training as much as possible, focus on the diversity and complexity of shipping talent demand, meet the needs of industry development and market, keep pace with the development of the times, keep pace with the development of the industry and keep proper advance. 
Base construction depends on the benefit cooperation mechanism of win-win innovation. College-enterprise cooperation or open talent training is an important way to solve the shortage of shipping compound talents and the imbalance of supply and demand structure of industry human capital. Its premise is to clarify a series of problems such as who trains, trains for whom and how to train. All participants in the base construction have their own interests, and cooperation based on interest coordination can make the base run continuously and exert their initiative and enthusiasm to participate in the base construction.

Base construction needs to improve the internal control mechanism of standardized management. It is necessary to define the personnel involved in base management and establish a clear system of post responsibilities. The person in charge of the base and the management personnel should define their own post responsibilities, and regularly assess their posts, so as to form a relatively stable team of high-level teachers and do a good job in tracking and researching personnel training.

Base construction needs to establish service promotion and exchange mechanism. We will publicize and promote the talent training service of the base in the society, give full play to the radiation function of the base, expand the base's social influence, and create a good social atmosphere for the training of shipping compound talents. Increase communication among bases, exchange teaching methods, experiences and information with each other, to achieve the purpose of sharing resources, learning from each other and improving together.

\section{CONSTRUCTION OF RESOURCE DATABASES}

\subsection{Construction of Expert Database}

The broadness, diversity and complexity of the connotation of shipping compound talents determine that the talent training expert database should have the advantages of extensive connection, talent gathering and knowledge intensive. The division of labor in modern shipping industry is more and more sophisticated, and the pace of knowledge updating is accelerating. The comprehensive knowledge structure, practical experience in many fields, and cross-border thinking ability are required for shipping compound talents. However, the teaching staff in the talent training base can't meet the training requirements of shipping compound talents because of their own knowledge structure and industry background. Therefore, how to resolve this contradiction has become an important prerequisite for improving the level and quality of talent training. It is necessary to introduce experts with leading role in the industry as "external expert" into the training of shipping compound talents, make up for the "short board" of insufficient specialization in the work of talent training bases and improve the working level.

Scientific and accurate selection of experts is very important for the construction of expert database and the training of shipping compound talents. The personnel entered the expert database should have the following principles:

Firstly, experts should have high-level professional achievements, certain academic authority, high research level and theoretical research achievements. Secondly, they should be well-known person in the industry. Thirdly, experts should have good political quality and professional ethics, a sense of social responsibility and rigorous work attitude, and can participate in related activities. Fourthly, the members are compatible with the connotation of shipping compound talents.

Members of the expert database can be selected by the following methods: selecting a number of wellknown experts from academia and industry in each industry, with a certain proportion of academic experts and industrial experts, which is beneficial to complement theoretical research and practical experience. According to the professional expertise and research direction of the experts hired, they can be divided into nine categories, such as shipping, shipbuilding, traffic management, logistics, IT, finance, trade, law and insurance, to highlight comprehensiveness, professionalism and pertinence.

Wuhan is rich in higher education resources, with a large number of well-known experts and scholars in academia and education. There are many shipping enterprises and institutions, and many industry professionals who are familiar with the industry and market and have rich practical experience. At the same time, IT, finance, trade, law, insurance and other industries are developed. In addition, Wuhan's strategy of building an international inland river shipping center will also attract experts, scholars and celebrities from relevant fields and industries at home and abroad, which provide innate advantages and good atmosphere for the establishment of expert database of compound talents training. The Yangtze River Shipping Industry Research Center, established by Wuhan Xingang Administrative Committee and Wuhan University of Technology, and has an expert database management office, and can become the construction and maintenance unit of the expert database.

\subsection{Construction of Online Course Resource Library}

The broadness, diversity and complexity of the connotation of shipping compound talents determine that talent training should be carried out in multiple levels, from multiple angles, and in multiple ways. In addition 
to the traditional face-to-face classroom teaching and lecture forum, online training provides a new way for the training of shipping compound talents, which can expand the coverage and distance of talent training, enrich the methods of talent training, innovate the concept and mode of talent training, enhance the dynamic and realtime nature of talent training, and enhance the intensive and efficiency of talent training. From the function of online course distance education, it can not only broaden the learning channels for students to obtain courses in multiple professional directions, but also provide extremely convenient and diverse network distance teaching services for the on-the-job personnel in port and shipping enterprises and institutions.

\subsubsection{Function Design of Online Courses}

Online curriculum construction is the construction of curriculum resources based on network environment. The construction of online courses for the training of shipping compound talents should take into account the great changes in the mode of dissemination of educational information, and the resulting great changes in training concepts, training models and teaching methods. The application of network in the field of personnel training provides a large number of convenient learning opportunities, rich teaching environment and teaching resources for the training objects of shipping compound talents, and makes the learning more independent and personalized.

Online courses for the training of shipping compound talents can be classified according to shipping, shipbuilding, traffic management, logistics, IT, finance, trade, law, insurance and other majors. The main functions of courseware resources can be divided into two parts. The first is teaching resources for teachers to attend classes. Another is the teaching resource library designed in the form of web pages for teachers to prepare lessons and students to learn. The main modules are shown in Figure 2 below.

\subsubsection{Learning Navigation}

This module provides convenient learning navigation. There are mainly three modules, one of which is the course introduction. This module introduces the background, purpose, using objects, requirements and main contents of the course, so as to facilitate learners to have a preliminary understanding of the course resources. The second module is knowledge query, which provides the function of searching related information according to chapters and knowledge points. The third module is resource expansion, which provides a shared platform for other courses, and attracts other online courses for the training of shipping compound talents at home and abroad.

\subsubsection{Online Learning}

This module is the core of the course learning based on the network environment, and it is constructed closely around the teaching activities of the course. This module is mainly designed in three parts. Firstly, online courses are mainly shown in the form of self-developed online courseware, which is composed of video, PPT presentation, pictures, flash and so on. Secondly, for the case practice, some actual cases in the shipping field are described, which help students do some analyses. Thirdly, course design helps students learn how to analyse and solve problems, which has six parts: design objectives, requirements, steps, reports and help tips.

\subsubsection{Teaching Activities}

For Discussion board, there are two ways of real-time counselling and answering questions. One is that teachers answer questions online in real time, students submit questions, teachers answer them directly, and the system stores that in the questioning and answering (Q\&A) database at the same time.

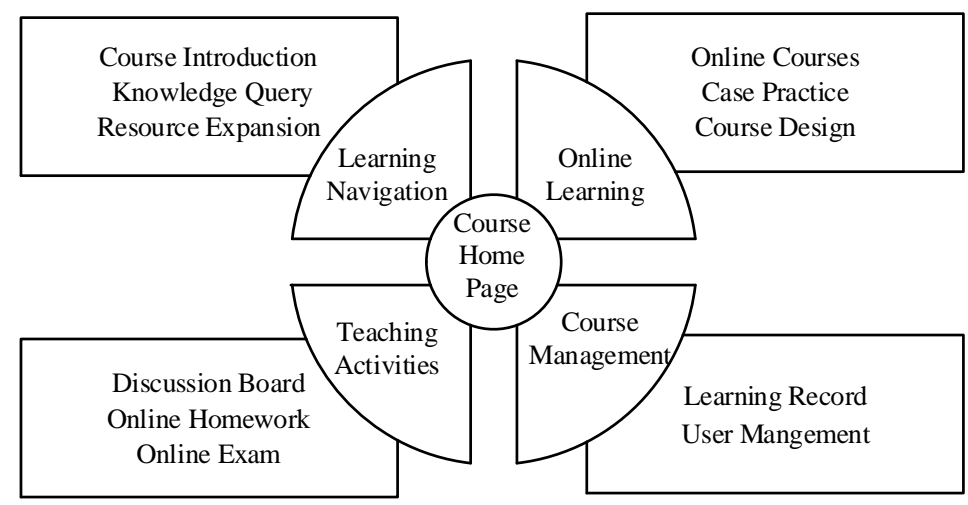

Figure 2 Online course function module of shipping compound talents training. 
Secondly, teachers store the common problems and difficulties in the Q\&A database to guide students to visit directly.

Learning evaluation combines with online homework and online examinations, which correspond to every chapter and are used to supervise and inspect the learning situation. These questions are arranged with optional questions, fill-in questions and design questions. Teachers correct questions online. Online exams can give scores immediately and record scores.

\subsubsection{Course Management}

This part has mainly two modules, one is learning record, and other is user management. Learning record takes the statistics of each student's learning performance and exam scores. For user management, there are mainly two types. The system administrators are manually added to the database by programmers when the system is initialized. Teachers are system administrator users, who can create, modify and delete other user information. The student users can enter the online course, after applying for the online course and obtaining the corresponding approval according to the permission setting of the online course.

\subsubsection{Course Resources Construction}

Set up a leading group of "Construction of Online Course Resource Library for the Training of Shipping Compound Talents", whose members include the responsible persons of various collaborative universities and units. Implement the chief expert responsibility system, openly appoint the chief expert, carry out project operation and gradually realize capitalization management. The online teaching platform, which is the carrier of online open courses in related universities, can be used to develop courseware resources, and these universities are responsible for the overall operation of online course courseware resources. The specific steps are as follows:

(1) Establish a scientific curriculum directory on the network teaching platform, and set up subdirectories, such as shipping, shipbuilding, traffic management, logistics, IT, finance, trade, law, insurance, etc.

(2) Hold the working meeting of the leading group of "Construction of Online Course Resource Bank for Training of Shipping Compound Talents", deploy related work, clarify the division of labor, decompose tasks, issue indicators and discuss related issues.

(3) According to the spirit of the working meeting of the leading group, set up a number of course groups, and define the main units and collaborative units.

(4) By means of centralized training, communication and self-study, experts and scholars can master the technical standards of online open curriculum construction, as well as the commonly used basic methods such as courseware making and modification, data downloading and collection and uploading, so as to better serve online distance teaching.

(5) Take the course group as the unit, be responsible for making, modifying and perfecting courseware, and do a good job of collecting and uploading data, and classify them into corresponding subdirectories.

(6) Set up the chief administrator of online course resource library for training shipping compound talents, regularly check and feedback the data uploading and application of each course group, and conduct comprehensive statistics every year.

(7) Establish a catalogue of online course resources for the training of shipping compound talents, so as to facilitate each expert, scholar and learner to find relevant teaching resources in time.

\section{CONCLUSION}

The shortage of shipping talents, especially highlevel shipping compound talents, has become a bottleneck restricting the rapid and sustainable development of the shipping industry. It is imperative to build a training platform for shipping compound talents by integrating the strength of shipping enterprises, colleges and industries. That will build a highland of shipping talents in the new period, speed up the cultivation of compound shipping talents, improve the comprehensive quality and innovation ability of technology, management personnel and shipping college graduates of port and shipping enterprises and institutions, fill up the shortcomings of high-end shipping services, and enhance the agglomeration and competitiveness of shipping industry.

\section{REFERENCES}

[1] Jiang Jun, Tan Ming. SWOT analysis and countermeasures of shipping talents in Chongqing $[\mathrm{J}]$. Journal of Chongqing Jiaotong University (SOCIAL SCIENCE EDITION), 2013, 13(02): 25-29. "In Chinese"

[2] Yang Dagang. Training of shipping financial talents based on "the Belt and Road Initiative" [J]. Shanghai Finance, 2015, (06): 109-110. "In Chinese". DOI: 10.13910/j.cnki.shjr.2015.06.021

[3] Qu Qunzhen, Li Lixin. Dynamic mechanism of innovative mode of shipping talent training[J]. Logistics Engineering and Management, 2014, 36(02): 166-168+162. "In Chinese"

[4] Lai Yongsheng. Implementation guarantee and evaluation of innovative shipping talent training mode of interdisciplinary cooperation $[\mathrm{J}]$. Market 
Weekly (Theoretical Research), 2017, (10): 136137. "In Chinese"

[5] Yin Ming, Zhang Qiang, Wang Xuefeng. Research on talent cultivation of shipping specialty based on supply side structural reform[J]. Navigation, 2017, (04): 15-18. "In Chinese"

[6] Wei Zhijie, Building Wuhan into China's highquality crew recruitment center and expatriate base[J]. China Shipping, 2016, (12): 20-22. "In Chinese”. DOI: 10.13646/j.cnki.42-1395/u.2016. 12.006

[7] Liu Lei, Chen Xiangguang, Fang Lei, Han Zhen. Study on the construction of teaching staff in maritime vocational colleges based on the cultivation of international shipping talents[C]. Proceedings of 2020 International Conference on Education, 2020: 155-159. DOI: 10.26914/c.cnkihy. 2020. 005209

[8] Gao Wenjing. Research on the development strategy of navigation education and training in response to international conventions based on "the Belt and Road Initiative"[C]. Proceedings of 2019 AsiaPacific Conference on Advance in Education, 2019: 772-776. DOI: 10.26914/c.cnkihy. 2019. 037500

[9] Wan Jianxia, Zhang Shunkui, Li Jing. Grey cluster evaluation model for competitiveness of area shipping talent[C]. Proceedings of 4th International Symposium on Social Science (ISSS 2018), 2018: 361-365.

[10] Pantouvakis A, Karakasnaki M. The human talent and its role in ISM code effectiveness and competitiveness in the shipping industry[J]. Maritime Policy \& Management, 2018, 45(5): 649664.

[11] Cheng Xiangxin, Wu Shuo. Analysis on the training of Shandong shipping talents[J]. Procedia Engineering, 2012, 29(29):

[12] Inayat I, Amin R, Inayat Z, Badshah K. A collaborative framework for web based vocational education and training (VET); Findings from a case study[J]. International Journal of Modern Education and Computer Science, 2013, 5(12): 54-60. DOI: 10.5815/ ijmecs.2013.12.08

[13] Khan S, Bakhsh S T. A study on the role of facebook in e-learning[J]. International Journal of Education and Management Engineering, 2015, 5(5): 1-11. DOI: 10.5815/ijeme.2015.05.01

[14] Herala A, Knutas A, Vanhala E, Kasurinen J. Experiences from video lectures in software engineering education[J]. International Journal of Modern Education and Computer Science, 2017, 9(5): 17-26. DOI: 10.5815/ijmecs.2017.05.03

[15] Fetaji B, Fetaji M, Ebibi M, Kera S. Analyses of impacting factors of ICT in education management: case study[J]. International Journal of Modern Education and Computer Science, 2018, 10(2): 2634. DOI: 10.5815/ijmecs.2018.02.03

[16] Carmichael D, Archibald J. A data analysis of the academic use of social media[J]. International Journal of Information Technology and Computer Science, 2019, 11(5): 1-10. DOI: 10.5815/ ijitcs. 2019.05.01 